\title{
SOME PERSONAL REMINISCENCES OF THE FIRST TWENTY PLUS TEN YEARS.
}

\author{
R. E. BEARD \\ London
}

Astin is formally twenty years old, or should I say young, and the occasion of the I 3 th Colloquium being held in the country where it was constituted seems a very suitable opportunity for making a record of the ten years prior to its formal constitution. This is a personal account and sets out facts and impressions which are now becoming coloured by the vagaries of memory; others will have their own impressions of some of the events and I hope will be stimulated to correct any biasses or to supplement the historical record.

Inevitably this record will not be complete and I apologise in advance for any significant omissions. Over the years I have accumulated a large mass of correspondence and had hoped to codify this in anticipation of this article but unfortunately a series of complications arising from my move to a part of rural England as a further stage in my retirement programme have delayed sorting through the mass of paper.

My interest in non-life insurance was first stimulated when I was involved in the early I930's in an analysis of the results of Fire and Auto Property business written in the US. This brought me face to face with the differences between the UK and US approach to profit measurement, in particular the real meaning of unearned premiums. The conventional UK method of basing the provision for unexpired risks on $40 \%$ of the premiums written during the year led to significant distortion in the emergence of profits (or losses) with an increasing volume of business, a large proportion of which was for periods of three years. Equally the US method of basing a statutory result without any allowance for the equity in the unearned premiums led to further distortions of the true profit, quite apart from the practice, then permitted, of substantial portfolio reinsurance transactions at the close of accounting periods. 
Other problems arose from the important changes in the exchange rates between the pound sterling and the US dollar and the conventional accounting treatment of such changes.

A critical analysis of the conventional accounting methods soon pointed up the weaknesses in much of the available statistical data and I was stimulated to seek ways and means of finding suitable measures for testing the significance of the variations shown by the conventional ratio comparisons. It was not long before it became clear that the appropriate starting point for a formal treatment was to express the premium rate as the product of a claim frequency rate and a damage degree factor; my slowness in reaching this conclusion was probably linked with the conventional UK actuarial approach to sickness problems, the nearest parallel, in terms of sickness cost.

Although it subsequently became apparent that the frequency times amount approach had been in use in the UK in the early Igth century and was in common use in Continental Europe, the evolution of the fire insurance market had meant that following the formation of the Tariff in the mid I860's the only statistics generally available for the UK were the results of companies expressed in terms of claims related to premiums. These figures were compiled on a net of reinsurance basis on a world wide basis and were thus of little value for analysis purposes. In the market and commercial environment this was not of great importance but the deficiencies of the approach became very apparent when the post second world war inflation set in. It is also important not to overlook the fact that the British insurance offices were engaged in developing internationally, providing the essential services needed to back up the expansion in world trade, so that the portfolios were far from homogeneous. In such circumstances there was little scope for sophisticated statistical methods, even if suitable techniques had been available.

Throughout the I930's my main work was in the conventional actuarial field and I was fortunate to be associated with the late Wilfred Perks. Among other things he stimulated my interest in mortality studies and I was soon exploring the consequences of replacing the assumption of homogeneity within age groups by other assumptions. The arithmetic soon became prohibitive as the 
basic problem was one of mixtures of distributions and it was to try and cut through this that I decided to construct a Differential Analyser, having already reformulated classical actuarial techniques in a form suitable for treatment by differential (or integral equations.

From I 942 to 1946 I was involved with the many problems arising from the operation of naval aircraft. Here the basic problems were best approached by a two factor approach, i.e. a rate of exit and a repair lag, but there were also subsidiary aspects such as the concepts of accident proneness and logistic problems which have since become the province of Operational Research.

On returning to the insurance business in I946 I became involved wholly on the non-life business and realised that practically all of my earlier experience was relevant to the analysis of the business. There were few UK Actuaries actively engaged in the business, the main educational requirements being met by the Chartered Insurance Institute. In 1947 the London Insurance Institute, the largest branch of the CII, inaugurated an Advanced Studies Committee, of which I became a member, and this gave me the opportunity of trying to interest the practitioners in statistical analysis. We formed one group to study the theory of risk but this made little progress as we were unable to obtain relevant data, largely because of the tariff structure of the market. However this activity brought me into contact with the late Ernest Eldridge which proved to be the beginning of my links with Astin. Ernest introduced me to Paul Johansen and to the late Boleslaw Monic. The latter was then actively building up an international reinsurance business and he soon became an important liaison between actuaries in many different countries who had similar interests to Paul and myself.

The 13th International Congress was held in Scheveningen in I95I and Ernest Eldridge requested that one of the Special Meetings be on the subject of Excess of Loss Reinsurance. We had very little idea of the likely support but in the event our original ideas had to be revised upwards as it became there was quite a large measure of interest. Altogether 59 persons signed the list with $I 6$ countries being represented. Papers were presented by B. de Jongh, Monic, Eldridge and myself. A lively discussion ensued and we were convinced that there was a case for further development. 
In Sept 1952 the Algemeene Herverzekering Maatschappij of Amsterdam (Monic's company) held a competition for papers on Excess of Loss Reinsurance. The prize winning papers and extracts from some others were published in 1955 and mark an important stage as they represent a balanced presentation of the application of modern statistical theory to a practical problem. Many of us felt at that time that the market was underpricing, such covers although it was some years before our fears were confirmed.

Meanwhile a Preparatory Committee had been formed and Prof. Edouard Franckx submitted a summary of its aims to the Council of the Comite Permanent at its meeting on 26 Sept. I953. Through its President the Council promised all support. Following this green light a letter was sent to a limited number of those present at the Special Meeting in Holland inviting them to become members of a proposed Association for Actuarial Studies in Non-Life Insurance. A draft set of rules was enclosed and the hope was expressed that it would be possible to arrange a private meeting in Madrid in I954 during the I $4^{\text {th }}$ Congress.

Agreement was given to hold a meeting in Madrid to found Astin and for another to discuss scientific papers but it became clear that a number of members of the Council were not happy with the proposed Association. These seemed to stem from the fear that a separate organisation might evolve, a reasonable enough thought and far from the minds of the Preparatory Committee; however, there also seemed to be an undercurrent of reluctance to becoming involved with extending actuarial techniques into the non-life field. The latter was never overtly expressed although I had become aware that there were pressures in a number of countries.

In the event the proposed formation meeting was not held but a private meeting was held to discuss papers prepared by Sternberg and Ammeter at which 37 persons were present.

Following this setback, Franckx, Johansen, Monic and myself formed a small committee to find a way through the difficulties. Thanks to wise counsels, in particular from Sir George Maddex, revised draft rules were prepared which reconciled the views of the founder members and the Council and at the meeting of the latter in Sept. I954 a formula was proposed that the rules of the Comite Permanent should be modified to permit the formation of specialist 
sub-groups. Draft proposals were discussed at the meeting of the Council in Sept. I955 and, after further work, agreement was reached in Sept. 1956 regarding the formal amendment to the rules of the Comité Permanent to be proposed at the Congress to be held in New York in 1957.

Final agreement on the Astin rules was reached by the sub-committee in March 1957 and attention was next directed to the problems to be faced in New York. The change of rules of the Comite Permanent would be made at the opening meeting of the Congress and arrangements had to be made for a meeting of interested persons to formally establish Astin, to elect a Committee and to confirm the proposed rules. Above all it was essential to secure a proper liaison with the Casualty Actuarial Society, which was in rather a special position vis-à-vis the Comité Permanent, and the geographical spread of the likely membership. It was also necessary to receive a nomination from the Council for a member to sit on the Astin Committee.

Thanks to help from quite a number of people the inaugural meetings went without a hitch. The Vice-President of the Congress, Albert Linton, Laurie Longley-Cook, Francis Perryman and Doc. Masterson spring readily to mind but there were many other wellwishers. The selection of Sir George Maddex as representative of the Council ensured that the formalities of the meetings would be handled with tact and understanding.

From this point on the development can be followed in the pages of the Astin Bulletin, with formal reports in the annual meetings of the Comité Permanent. The following remarks have no chronological significance but are essentially random jottings.

We thought that the active membership might number a few hundreds when Astin had reached maturity. How wrong we were is shown by the growth to over I200 and still growing. The scope has quietly been extended to make it clear that risk is a basic part of our activity and the Bulletin is now an established reference in the applied probability/statistics field. Papers have established new results in scientific theory but have also covered a wide range of practical and theoretical aspects of the non-life insurance business. There has been increasing emphasis on the application of science to the management problems. There has been a growing impact on 
traditional actuarial activities and the interest shown in risk theoretical applications, which are particularly apposite in today's conditions, is likely to increase. Few actuarial societies do not now include elements of risk theory in their courses of study or examinations. Filip Lundberg's first paper appeared 74 years ago and many of today's applications may seem remote but the flow continues.

These are the visible results but to my mind the far more important aspects of Astin are the friendships which have become possible through the meetings of minds motivated by common interests. Our meetings have been truly international and the friendships have withstood the undoubted strain of trying to understand my meaning when I have endeavoured to converse in other than my native tongue. My service as Secretary and for a while as Editor of the Bulletin and the honour of being Chairman was a very happy period, even if there were times when diplomacy had to be buttressed by appeal to the rules which experience has shown to have functioned well. The Committee members are, of course, individuals, selected because of their personal interest in our affairs but they have always acted in the interests of all the members so that the problems of a world-wide membership have never been pressing. There have been some tense moments but always they have been resolved without acrimony and with good will.

Last, but not least we should never have succeeded if it had not been for the co-operation of our ladies. Even the strict separation of the Rattvik Colloquium did not discourage them from subsequent Colloquia where it has always been a pleasure to renew their acquaintance. 